and rhenium. A third congener, which would have an atomic number of 93 and would thus be the next element beyond uranium, was announced by Koblic in $1935^{18}$. It was said to be present in certain residues from the working up of pitchblende for radium at Jáchymov (St. Joachimsthal), but as spectroscopic examination failed to reveal any new body, Koblic soon withdrew his claim to the discovery of bohemium, as he called the new element. In passing, it may be mentioned that in 1934 the hundredth gram of radium was extracted at Jáchymov, though by that time the Czech source of radium and pitchblende had lost its importance since far greater supplies are available in the Belgian Congo and near the Great Bear Lake in Canada. Nevertheless, Czech chemists and radiologists made valuable studies and applications of their supplies, particularly in medicine.

Brauner's life and work were influenced not only by his contacts with Mendeléeff but also by his connexions with Great Britain. His first interest in England began when as a boy he received a chemical set known as "Tutton's Chemical Box", which Prof. Frič took back to Prague from London. Later, in the 'eighties, he studied at Manchester under Roscoe and afterwards revisited England, taking the opportunity to read some papers before the Chemical Society ${ }^{19}$. It therefore became a part of his tradition that promising students were sent abroad to widen their outlook. Thus Sterrba-Böhm went to Paris to work under Moissan and Becquerel, Heyrovský came to London to hear Ramsay, Donnan and many other contemporary great chemists, Krepelka went to the United States to work under Richards. Between 1918 and 1938 a number of Czech students went abroad to spend at least a year of their academic life under Western influence. To-day it is only abroad that they are able to continue their researches and studies, for in the "protectorate" all universities and institutes are closed. When the nation is again liberated and the universities are opened once more, there is no doubt that the Mendeléeff-Brauner tradition of Czech chemistry will again inspire the nation's chemists to achieve results for the general advancement of science and the welfare of mankind.

\footnotetext{
II March 1869, Mendeléeff circulated a memoir among members of the Russian Ohemical Society. It set out his views on the periodi city of the elements and contained his first Periodic Table. The memoir was later reprinted in the Society's Journal.

2 For example, in his "Principles of Chemistry".

a NATURE, 109, 552 (1922).

4 Chem Listy, 2, 30, 87, 129 (1877).

${ }^{5}$ J. Chem. Soc., 41, 68 (1882); Ber., 11, 872 (1878).

- J. Chem. Soc., 67, 549 (1895).

Rec. trav. chim., 44, 281 (1925).

${ }^{8}$ Collection Czech. Chem. Comm., 7, 57 and 131 (1936).

- Collection Czech. Chem. Comm., 5, 233 (1933).

${ }^{10}$ Collection Czech. Chem. Comm., 10, 8 (1938).

${ }^{21}$ Collection Czech. Chem. Comm., 2, 255 (1930); Chem. Listy, 19, 158 (1925).

23 NAture, 119, 348, 526 (1927); J. Amer. Chem. Soc., 42, 155 (1920).

${ }^{2}$ Collection Czech. Chem. Comm., 2, 1 (1980).

"Rec. trav. chim., 44, 488 (1925). Several monographs have recently appeared dealing with polarography, and there is an extensive
list of references in Chemistry and Industry, 60,778 (1941).

16 NATURE, 117, 782 (1925).

16 NATURE, 111, 79 (1923).

17 Chemistry and Industry, 42, 884 (1923).

${ }_{18}$ NATURE, 134, 55 and 282 (correction) (1935).

1. Proc. Chem. Soc., 67-72 (1898); ibid., 63-68 (1901).
}

\section{LANDSCAPE IMPRESSION AND THE EXTERNAL BASIS OF NATURAL BEAUTY}

\author{
By L. C. W. BONACINA
}

T $T$ is often said with some truth that this century I has seen a welcome change from the last towards a desire to bring scientific knowledge and $x$ sthetic appreciation of Nature more into line in human thought. Yet there were already signs of a change of outlook during the nineteenth century. That shrewd cosmopolitan thinker, Alexander von Hum. boldt, who helped to lay the foundations of so many of the geophysical and geographical sciences and saw so much of Nature in many lands, considered that it was not altogether possible to dissociate æsthetics from science in the study and contemplation of landscapes. As to Victorian England, it is in. structive in this regard to note the respective attitudes of Tyndall and Geikie, for example, in science, and of Ruskin and Wordsworth in art and poetry.

Whatever may have been John Tyndall's theological views there can be no question that the whole outlook upon Nature of this celebrated physicist was consciously and deliberately artistic, and there are passages in his "Hours of Exercise in the Alps" which almost vie in descriptive power with Ruskin himself, leaving the reader with the conviction that to this great-hearted Irishman there was much more in the mountains than was comprised in their dimensions, form, structure and composition. Similarly, the eminent Scottish geologist, Sir Archibald Geikie, displays in his "Landscape in History and other Essays", which considers the human response to different types of country in Great Britain as also in Italy and Greece, highly imaginative insight into those imponderable but powerful environmental influences so vividly reflected in literature. Conversely, though the art critic, John Ruskin, may have given vent to irritable denunciations of scientific research, no one more loudly proclaimed the importance for creative work of careful and accurate, that is, scientific observation of natural phenomena, even going so far as to declare quite unjustly to Constable and others that no landscape painter before Turner had ever really looked at the clouds. In like manner, though William Wordsworth may have passed occasional rude remarks about geologists and astronomers, there is something in his very Naturemysticism, unique among the great English poets, which is very reassuring from the wider philosophical and scientific point of view, and it is surely significant that a Wordsworthian text should have been selected as a motto for NATURE. Throughout Wordsworth we discern in the background tacit acceptance of scientific principle which makes for stability and enhances the value of much deep and passionate expression of feeling. There is a curious passage in the second book of "The Prelude" wherein the poet is thinking of the sun and moon both as cosmical bodies and as elements in the local landscape, and says of the latter, with respect to a beloved Cumbrian vale, that she hung

"Midway between the hills, as if she knew

No other region, but belonged to thee,

Yea, appertained by a peculiar right

To thee and thy grey huts, thou one dear Vale !" 
This passage is valuable as seeming to illustrate a difficult, almost painful, spiritual attempt on the poet's part to co-ordinate and harmonize astronomical knowledge with artistic perception of the moon in relation solely to the local scene. It typifies that dual attitude of mind which every contemplative lover of Nature who is both man of science and poetical impressionist will find daily opportunities to exercise.

We are now in the twentieth century in sight of a more rapid convergence of the paths followed by the scientific investigator and the interpreter of natural beauty which, it is to be hoped, will eventually unite into one clear line of approach to truth about the external world. It is highly probable that the change is being accelerated in large measure by the fact that the various theoretical enigmas and paradoxes accruing to the great modern discoveries in physics and biology, together with the perplexing farreaching implications of the doctrine of relativity, have taken us, metaphysically speaking, out of our depth, but in so doing have served to break down the hindering rigid distinction between 'subjective' and 'objective' fact which formerly appeared final. To-day the very meaning of traditional conceptions is becoming strained and challenged to such an extent as to force thinkers into the wholesome practice of putting in inverted commas all controversial terms which it seems to them either have not been, or cannot be, exactly defined.

Hence it seems fitting at the present time to reconsider the question whether the quality of beauty cannot be brought into closer scientific relationship with the grosser attributes of natural phenomena. If those who study Nature from the æsthetic side will help men of science by paying attention to accuracy of observation and to the subjection of their flights of imagination to scientific discipline, they will find themselves automatically in scientific company without loss of any power in their own proper sphere. Reciprocally, if men of science will respond to the overtures of artists and boldly zonfront the question whether natural beauty with all the ennobling emotions which it begets may not be something deeper and more systematized than a wayward subjective reaction to mere matter, they may soon discover fresh vistas opening out before them, so enlarging the scope of their own endeavours. It is indeed imperative in this complicated problem that scientist and artist should work together in order constantly to put questions to one another which neither would think of in isolation.

Landscape is not, of course, the only source of the experience of natural beauty, but since it comprises so much of human environment it affords a peculiarly convenient and effective one for the interchange of ideas as between science and æsthetics. For in the landscape the observer, whether scientific or artistic, becomes aware of a multitude of sense impressions from earth, water and sky for the descriptive differentiation of which language is quite inadequate. Words fail, for example, to denote the distinctive shades of 'green' which characterize the summer foliage of various species of trees even in identical illumination. In short, landscape observation brings both the seeker of physical facts and the lover of beauty up against the subtler truths of sense impression, and this in itself is a valuable corrective of the dangerous tendency of the human mind to think in categorical or class concepts in consequence of the limitations of speech. It is seldom suspected that a large amount of unnecessary controversy in many a field of thought arises out of the fact that the names we bestow on common objects, qualities and phenomena are in essence class-concepts concealing differences between members of the same group. This is why statistics involving broad categories are inherently dangerous and require much care in their interpretation. Contrariwise, it is the peculiar value of landscape impressionistic study that it leads to the intensive exereise of every sense-faculty, and thus invites the scientific observer and the artistic observer to walk together and exchange experiences derived from the concrete presentation of particular scenes. When the senses perceive so much more of reality than words can cope with, classes and categories, which are, after all, only mental attempts to arrange Nature's bewildering medley of overlapping, interlocking facts, are soon forgotten.

The question whether beauty is a quality residing in the object perceived or in the mind of the perceiver has long been at issue in philosophical circles, but this provides yet another example of the common fallacy of expecting a simple answer to an intricate question. It is very doubtful, indeed, whether the metaphysical distinction between beauty as a 'tertiary' attribute of matter, colour as a 'secondary' attribute and shape as a 'primary' attribute will bear searching logical analysis, for obviously beauty has certain objective or external foundations whatever purely subjective or personal elements may enter into its evaluation. The external physical basis of beautiful scenery consists in the association of a vast number of elements of form, colour, lighting, movement and the like, an association in which the human spirit discerns harmonious relationship. Now it is admitted that without sentient creatures all the wealth of landscape expressed in light, colour, sound and scent would vanish from the world even though the physical counterparts thereof as electromagnetic vibrations, air-waves and corpuscular emissions would remain. Similarly, though beauty as such might cease to exist upon the earth in the absence of man with his higher spiritual faculties, the physical counterpart thereof, namely, certain pictorial relationships of material elements, would be there just the same, for the external basis of a beautiful view does not depend on the presence of a spectator. It has been argued against the reality of any objectivity in natural beauty that people appreciate it so differently, some being largely blind and insensible thereto; but it might as well be argued against the reality of the grosser attributes of matter that some persons, through physical blindness or deafness, cannot see or hear them. Certainly in the exercise of a spiritual faculty like the æsthetic sense there should be scope for beauty to be variously interpreted, since different minds will tend to capture different aspects of the truth; but within such diversity there is a large measure of unity, particularly among persons of culture. When a common standard of reference for æsthetic values has been discovered, defined and agreed upon, the fallaciousness of this kind of argument will become apparent.

As the medium through which the scenic glory alike of the heavens and the earth is witnessed by the observer, the atmosphere plays a highly critical part, because every scene must be viewed through some sort of light and weather. In fact, the diversity of scenic moods exhibited by every landscape is evidently in response to a delicate balance of meteorological factors. The fact in itself opens out a promising field for joint investigation by artists and 
meteorologists, as I have shown elsewhere in a series of essays on landscape meteorology. Readers of Thomas Hardy, who so skilfully portrayed his Wessex characters against what might be called the 'elemental' background of solitary heaths, woods and downs, may recall a passage in "The Return of the Native" wherein it is told that the great Dorset Heath could by its very expression anticipate the frowning of storms scarcely generated. This is more than a vivid local picture inasmuch as it typifies the mysterious manner in which the aspect of the country the world over responds to subtle unsuspected changes proceeding in the atmosphere, as though the slightest alteration in its physical condition as to light, temperature, moisture and other factors produced its counterpart in the æsthetic expressions of mountain, sea, forest, lake and the like. Theoretically it should be possible to relate the atmospheric states to the scenic expressions of the landscape, but in practice it might prove impossible to scrutinize the air with the closeness which a problem of such extreme intricacy would require. Nevertheless, the attempt would be well worth while if only it resulted in the formulation of a new vocabulary for the description of the 'scenic expression' in terms satisfactory to artists and men of science alike.

A suggestive fact in the problem of landscape beauty is the relationship between kindred features as members of a company. Just as a human personality needs to be drawn out by others, so does the scenic individuality of the trees, rocks and hills gain by interrelationship. We know how in a mountainous land the great peaks impart to one another a bearing which enhances the grandeur of the whole array, giving a new meaning to the music of torrent and cataract and the picture of gleaming glaciers. Similarly, along a high rugged coastline is it not the viewing of the multitude of rocky profiles in mutual relationship which gives the cliff scenery much of its inspiring character as we listen to the rhythmic impact of storm-waves or the low sinister murmur always uttered by the sea on such a coast in quiet weather? Sometimes, too, the very clouds gather in noble companies, as when gloriously lit in rifted storm masses-not the less suggestive because so transient. Then take the trees. Solitary trees admittedly can be superb, as a spreading oak or beech in field or park, a commanding ash on the skyline, a graceful birch at the entrance to a Highland glen, a shapely hawthorn in full blossom on the hillside, or a rowan tossing in wind and spray amid the boulders of a moorland stream; but it is nevertheless true that when trees of the same species grow in company with ample room for free individual development their beauty is intensified by pictorial interrelationship. Thus lofty elms often form groupings of the utmost elegance about English country lanes and village churches; but perhaps nothing in tree-beauty can exceed the magnificence at all seasons of the year of a fraternity of great oaks disposed or inclined towards one another in every comely posture, as commonly at the foot of a range of hills. In short, the universality of this kind of scenic companionability throughout the types of Nature furnishes a fundamental fact for contemplation and will demand much thought as the foundations of beauty are sounded.

The part played by animals in scenic beauty though, perhaps, less obtrusive than that by plants, is nevertheless of great importance in introducing two distinctive esthetic elements, the one of living forms in motion against the physical background, and the other of mental reactions to the environment, both of which add much to our human sense of the geographical personality of different regions. This is a strong argument, apart from other reasons, for the strict preservation of what remains of the indigenous fauna of Britain or of any other country where the fauna is threatened. The song and notes of wild birds are so essentially part of the beauty of the landscape that it becomes a question to what extent our enjoyment of them, unlike that of the more elaborate musical compositions of man, really depends on this fact. Thus a divine melody of Chopin or Schubert need lose nothing from being heard in a city slum, but it is at least arguable whether the full emotional appeal of the trills and cadences of the nightingale is not inseparable from the sight or memory of such an associated setting as a flowery woodland dell or garden shrubbery in the month of May. Again, though the plaintive ery of lapwings may not be particularly beautiful in itself, it can become decidedly inspiring when these hand. some plovers are seen with cattle and horses wheeling in a half stormy light over vividly green, highperched meadows climbing up to moorland, as typically in Devon and other western counties.

Evaluation of the objective foundations of natural beauty is, of course, affected by various personal factors as, for example, knowledge, which is often a safeguard against spurious, illusory or incomplete impressions. Thus at least an elementary knowledge of the geological structure of a locality is essential to the full measure of appreciation of the beauty of the countryside. An artist would certainly miss the whole rsthetic scheme of the Wealden landscapes of Kent, Sussex and Surrey, for example, if he did not appreciate the difference of contour line and of vegetation characteristic of the great parallel ranges of chalk, greensand and Wealden sandstone similar in altitude and regional climate. Knowledge of history and purpose may be the means of awakening a person's susceptibility to the exquisite beauty of our Gothic cathedrals, just as, on the other hand, it has been said that visitors to the Great Pyramid have turned away in disgust on being told that it was built by sweated labour-insensible to its symmetrical perfection which is there all the same. Perhaps in the end they who find it difficult to divoree moral principles from physical attributes may be right.

Finally, we come to the question of the metaphysical meaning of the external basis of beauty. We have seen that it needs mind to translate these external qualities into the actual spiritual experience of beauty, but why should they be present in Nature to be so translated at all ? Whence comes this mysterious expression of harmonious relationship between the component parts of what is called gross matter ? It is a proposition difficult to dispute that the physical universe does actually possess the power to excite æesthetic emotions, and if this be really the fact it points strongly to the position of those philosophers who hold that the background of the universe is mental and the expression of intelligent Deity. Beauty is part of the manifestation of law and order throughout Nature, and its existence implies that the various elements comprising a landscape or other medium exhibiting beauty are related to one another in a manner capable of arousing spiritual pleasure in the beholder. Now if we admit that man's æsthetic faculty may have been evolved in response to some real counterpart existing in Nature in her own right, 
we may find ourselves on the verge of new knowledge concerning the relation of the human soul to its physical environment; whereas, if we cling to what would seem to be the traditional view that the sense of beauty invests Nature with attributes she does not properly possess, being no more than a private personal subjective reaction to external influences, we shall never get the subject of beauty outside human psychology. The latter alternative spells sheer frustration, whereas the former at any rate looks promising. With this crucial issue the problem must be left for the present, but the article may appropriately be concluded with a quotation from the concluding chapter of the late Mr. J. W. N. Sullivan's "Bases of Modern Science": "The fact that a piece of matter has been reduced by relativity theory to a system of events, that it is no longer regarded as the enduring stuff of the world, makes the hypothesis that the 'physical' and the 'mental' are essentially similar very possible. . . . Our æsthetic and religious experiences need not lose the significance they appear to have merely because they are not taken into account in the scientific scheme. It is indeed possible that they will not always remain excluded from the scientific scheme." It is my growing belief that they will not and cannot remain so excluded.

\section{ROLE OF HYALURONIDASE IN FERTILIZATION}

\author{
By Dr. D. MCCLEAN \\ Lister Institute of Preventive Medicine, Elstree, Herts \\ and
}

\section{DR. I. W. ROWLANDS}

National Institute for Medical Research

\begin{abstract}
$\triangle$ QUEOUS extracts of mammalian testis contain A a 'spreading' factor which dramatically increases the permeability of the skin to injected fluids. This factor is associated with the germinal epithelium and can be extracted from spermatozoa ${ }^{1}$. Factors with similar diffusing properties have been obtained from the most diverse sources, for example, from culture-filtrates and extracts of many species of invasive bacteria ${ }^{2}$, from snake and spider venoms ${ }^{3}$ and from leeches ${ }^{4}$. Chain and Duthie ${ }^{5}$ reported a remarkable mucolytic activity of these extracts characterized by a rapid fall in the viscosity of synovial fluid and the liberation of reducing substances. This observation has been confirmed and extended by other workers and it appears that these spreading factors are closely associated if not identical with a group of enzymes that hydrolyse the hyaluronic acid of the synovial fluid, vitreous humour, umbilical cord and skin', and which are therefore known as hyaluronidases.
\end{abstract}

The role of the hyaluronidase of spermatozoa in fertilization has not hitherto been explained. Experiments designed to show whether this enzyme causes an increase in the permeability of echinoderm eggs comparable with that occurring immediately after fertilization yielded negative results? Recent (unpublished) observations on the activity of the enzyme on bovine cervical mucin during ostrus and in the resting phase were also negative.

The presence of a transparent, viscous fluid or gel in which the cumulus cells and corona radiata surrounding the tubal egg of the rat are embedded was described by Long ${ }^{8}$. The removal of this substance and the consequent disintegration of the cell mass is necessary to enable the sperm to penetrate the egg. According to Pincus and Enzmann" the dispersal is brought about by a heat-labile substance produced by the spermatozoa. Earlier work by Yamane ${ }^{10}$ showed that a preparation of pancreas removes the cells surrounding the egg of the rabbit, an observation which was confirmed by Pincus and Enzmann ${ }^{11}$, who used purified trypsin. They observed, however, that in addition to removing the cells, partial digestion of the egg occurred, and so it is highly improbable that the process of denudation of the egg in the Fallopian tube is effected by trypsin or a similar proteolytic enzyme. The facts recorded above suggested that hyaluronidase might be responsible for the phenomenon, and the following experiments were carried out.

Ovulation was produced in immature rats and the eggs removed from the Fallopian tube as previously described ${ }^{12}$. The action on the gel and cell masses of hyaluronidase obtained from various sources (see table below) was investigated. In addition, the supernatant fluid of a centrifuged suspension in Baker's solution ${ }^{13}$ of rat sperms killed by heating at $50^{\circ} \mathrm{C}$. for five minutes and a similar preparation of rabbit semen were tested, together with the secretions of the seminal vesicles (vesicular fluid) and prostate of adult rats. The action of some detergents such as sodium glycocholate was also recorded. The action of all these substances was observed in the following manner : $0.2 \mathrm{ml}$. of saline $(0.8$ per cent sodium chloride) was pipetted on to a watch-glass and an equal volume of enzyme dilution added and mixed. A cluster of 6-12 eggs was then immersed in the mixture and the rate of dispersion of the cells

THE $\triangle$ OTION OF HYALTRONIDASE AND OTHER SCrRSTANCES AND PREPARATIONS ON THK DISPERSION OF THE CUMULOS CELTS OF THE RAT DVCM.

\begin{tabular}{|c|c|c|c|}
\hline \multirow[b]{2}{*}{ Substance tested } & \multicolumn{2}{|c|}{ Hyaluronidase } & \multirow{2}{*}{$\begin{array}{l}\text { Time taken to } \\
\text { disperse cumnlus } \\
\text { cells and corona } \\
\text { radiata (min.) }\end{array}$} \\
\hline & v.r.u./ml. & m.c.p. & \\
\hline $\begin{array}{l}\text { Bovine testis hyaluron- } \\
\text { idase }\end{array}$ & $\begin{array}{c}0.6 \\
0.85 \\
6.0 \\
8.5 \\
15 \cdot 0 \\
15 \cdot 0 \\
30 \cdot 0 \\
60 \cdot 0 \\
85 \cdot 0\end{array}$ & & $\begin{array}{r}165 \\
142 \\
36 \\
33 \\
20 \\
20 \\
17 \\
11 \\
9\end{array}$ \\
\hline $\begin{array}{l}\text { Streptococcal hyaluron- } \\
\text { Idase }\end{array}$ & $0 \cdot 6$ & & 100 \\
\hline$C l$. welchii hyaluronidase & $\begin{array}{l}6 \cdot 0 \\
5-7 \cdot 5\end{array}$ & & $\begin{array}{l}32 \\
27\end{array}$ \\
\hline $\begin{array}{l}\text { Vibrion septique hyal- } \\
\text { nronidase } \\
\text { Rattlesnake venom }\end{array}$ & $\begin{array}{c}10-15 \\
2 \cdot 5\end{array}$ & & $\begin{array}{l}19 \\
30\end{array}$ \\
\hline $\begin{array}{l}0.5 \% \\
0.05 \%\end{array}$ & & $\stackrel{+}{+}$ & $\begin{array}{l}17 \\
27\end{array}$ \\
\hline Rat sperm extract & 3.95 & + & 12 \\
\hline $\begin{array}{l}\text { Rabbit semen extract* } \\
\text { Rat and guinea-pig vesi- }\end{array}$ & 5.20 & + & 18 \\
\hline cular fluid & & - & No effect in $2 \mathrm{hr}$. \\
\hline $\begin{array}{l}\text { Rat prostatic fluid } \\
\text { Taka diastase, } 0.5 \%\end{array}$ & & 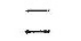 & " $78 "$ \\
\hline $\begin{array}{l}\text { Diastase, } 0.5 \% \\
\text { Sodium glycocholate }\end{array}$ & & - & No effect in $3 \mathrm{hr}$. \\
\hline $0.5 \%$ & & - & ", \\
\hline $\begin{array}{l}\text { Baker's solution } \\
\text { Physiological salt solution }\end{array}$ & & - & $\ddot{\prime \prime} \quad "$, \\
\hline
\end{tabular}

- Ten minutes heating at $100^{\circ} \mathrm{C}$. destroyed activity as shown both by $m$.c.p. test and inability in a period of 3 hours to disperse the cells surrounding the egg. 